\title{
СУЧАСНИЙ ПОГЛЯД НА ЗНАЧЕННЯ ЛЕКЦІЇ В НАВЧАЛЬНОМУ ПРОЦЕСІ
}

\author{
В. Г. Дубініна, О. В. Кузнецова, А. І. Рибін \\ Одеський національний медичний університет
}

\section{MODERN OPINION ON THE SIGNIFICANCE OF LECTURE IN EDUCATIONAL PROCESS}

\author{
V. H. Dubinina, O. V. Kuznetsova, A. I. Rybin \\ Odesa National Medical University
}

\begin{abstract}
Сьогодення вимагає від нас використання нових методів та методик, впровадження новітніх технологій, різноманітності підходів і поліпшення якості викладання. Лекція залишається на сьогодні традиційно провідною формою навчання у ВНЗ. Метою нашого дослідження було визначення значимості і місця лекції, а також значення особистості лектора на сучасному етапі кредитно-модульної системи навчання студентів вищого навчального закладу. Протягом 1 року ми пропонували всім студентам 5 курсу оцінювати якість викладання предмета “Онкологія" на основі анонімного анкетування. При цьому студентам першої групи лекції читали професор і доценти, які мають більше 10 років викладацького стажу і активно займаються лікувальною роботою, а студентам другої групи лекції читали молоді асистенти, зі стажем викладацької роботи до 2 років. Від майстерності і досвіду лектора залежить максимальне використання потенційних можливостей лекції, як провідної форми навчання, а саме науковий рівень підготовки студентів і мотивація до вивчення предмета. Процес навчання, починаючись на лекції, продовжується на практичних заняттях і поглиблюється самостійною роботою.
\end{abstract}

Now requires us to use new methods and techniques, introduction of newest technologies, the variety of approaches and improving the quality of teaching. The lecture is traditionally the leading form of education. The aim of our study was to determine the significance and place lectures, as well as the value of the person lecturer at the current stage of credit-modular system of training of students of higher educational institutions. Within one year we have offered all of the 5-year students to evaluate the quality of teaching on "Oncology" on the basis of anonymous questionnaire. The student of the first group lectures were given by Professor and Associate Professors, who have over 10 years of teaching experience and are actively involved in medical work, and the students of the second group lectures were young assistants, with a teaching experience of two years. From the skill and experience of the lecturer depends maximum use of potential opportunities of lectures as a leading learning, namely the scientific level of preparation of students and their motivation for learning. The learning process, beginning at the lectures, continues on practical exercises and more independent work.

Від поганого початку $і$ кінецьь буває поганий.

Eвpinid

Вступ. Сьогодення вимагає від нас використання нових методів та методик, впровадження новітніх технологій, різноманітності підходів і поліпшення якості викладання. Але не завжди “нове” краще і ефективніше "давно забутого старого”. Лекція залишається на сьогодні традиційно провідною формою навчання у вищому навчальному закладі (ВН3). Будучи головною ланкою дидактичного циклу навчання, вона виконує наукові, виховні та світоглядні функції, вводить студента в творчу лабораторію лектора. В житті сучасної вищої школи лекцію часто називають "гарячою точкою”. Яскраві сторінки в історії розвитку лекційної

() В. Г. Дубініна, О. В. Кузнецова, А. І. Рибін форми навчання вписав засновник першого вітчизняного університету М. В. Ломоносов, високо цінував живе слово викладачів. Він вважав за необхідне систематично і наполегливо вчитися красномовства, під яким розумів "искусство о всякой данной материи красно говорить и тем преклонять других к своему об оной мнению”. I тому він радив лекторам “paзум свой острить через беспрестанное упражнение в сочинении и прочзношении слов, а не полагаться на одни правила и чтение авторов".

Лекція-методологічна та організаційна основа всіх форм навчальних занять, у тому числі самостійних. Методологічна основа - оскільки вводить студента в науку взагалі, додає навчальному курсу концепту- 
альність, а організаційна - оскільки всі інші форми навчальних занять, так чи інакше, “зав’ язані” на лекцію, найчастіше логічно слідують за нею, опираються на неї змістовно і тематично.

За силою особистого емоційного впливу лектора, його контакту з аудиторією, виробленого враження, загального впливу на студентів лекційний спосіб передачі навчального матеріалу найбільш вдалий. Лекція розкриває понятійний апарат конкретної галузі знання, проблеми, логіку, дає цілісне уявлення про предмет, показуючи його місце в системі науки, зв’язок зі спорідненими дисциплінами, збуджує інтерес до предмета, розвиває професійні інтереси, значною мірою визначає зміст інших видів занять.

Мета дослідження: визначити значущість і місце лекції, а також значення особистості лектора на сучасному етапі кредитно-модульної системи навчання студентів вищого навчального закладу.

Ми не раз чули від наших більш досвідчених “старших" колег, що ніхто так добре не прочитає лекцію студентам, як молодий асистент. Тільки що прийшов на кафедру співробітник, з запалом береться за доручену йому роботу і готується до лекції, використовуючи наявні у нього матеріали, в кращому випадку - монографії та журнали, а в гіршому випадку Інтернет. Але, на жаль, отриманий таким чином матеріал не $є$ істинною лекцією, а всього лише реферат на запропоновану тему. І в цьому його звинувачувати не можна, він не винен. Справжній викладач, педагог за покликанням, готується до лекції не напередодні або за годину - дві до початку, а завжди, протягом усієї своєї діяльності, все життя.

Тому що основне завдання лектора не тільки піднести аудиторії інформацію в повному обсязі за заданою темою, але і зацікавити студента так, щоб, повернувшись додому після лекції, він захотів доповнити отриману інформацію і звернувся б вже самостійно до монографій і журналів. "Постав над собою 100 вчителів - вони виявляться безсилими, якщо ти не можеш змушувати себе і сам вимагати від себе" (В. А. Сухомлинський).

Особливо дієва авторська лекція, коли йдуть не стільки на дисципліну, скільки на “лектора". Тімірязєв говорив $з$ цього приводу, що лектор повинен бути не фотографом, але художником, не простим акустичним інструментом, передаючи усно побачене 3 книг, все повинно бути переплавлено творчістю. Згідно 3 Тімірязєвим, лекції повинні поєднувати правильність вирішення наукових проблем з пристрасністю, захопленістю ідеєю. На хороших лекціях процес розгляду навчальної інформації цілком керований, і зворотний зв’ язок, який для цього необхідний, реально існує. На посередніх ж і слабких лекціях зворотний зв' язок проявляється по-іншому, там дійсно студенти тільки роблять вигляд, що слухають, а іноді і не приховують, що не слухають, займаючись іншими, сторонніми справами. Відвідування таких лекцій дійсно має лише формальний характер.

Яким чином нині можна зацікавити сучасного досвідченого студента медичного ВНЗ? Мультимедійна презентація, фільми з оперативними втручаннями, таблиці, малюнки, рентгенограми... в даний час є невід'ємною частиною навчального процесу, і здивувати можна тільки якістю виконання і унікальністю. А от особистий досвід, що запам'ятовується, приклади з власної лікарської практики, демонстрація тематичних хворих - це те, що може і повинно стати родзинкою лекції і зацікавити студентів. I, на жаль, лекції молодих асистентів довгий час позбавлені цієї самої родзинки через відсутність у них клінічної практики. На лекціях необхідне раціональне чергування підвищеної уваги, розумової напруги i послаблення їх шляхом відповідної розрядки. В навчальному процесі, в тому числі на лекціях, важлива також творча обстановка. Досвідчений педагогвикладач вносить у свою мову живі образні порівняння, метафори, щоб його думки сприймалися дохідливо, переконливо, з інтересом.

Основна частина. Для того щоб підтвердити або спростувати сказане вище, колектив працівників нашої кафедри онкології з курсом променевої діагностики і терапії Одеського національного медичного університету (ОНМедУ) зважився на експеримент. Протягом 1 року ми пропонували всім студентам 5 курсу оцінювати якість викладання предмета “Онкологія" по закінченню 10-денного циклу. Оцінка проводилася на підставі анонімного анкетування, що складається з декількох пунктів. Але для даного експерименту, на нашу думку, пріоритетними питаннями були:

- Що вам сподобалося?

- Що вам не сподобалося?

• Які лекції вам найбільше запам'яталися і чому?

При цьому в першому семестрі експериментального навчального року студентам $(n=55)$ лекції читали як зазвичай за програмою професор і доценти, які мають більше 10 років викладацького стажу і активно займаються лікувальною роботою (1 група). А у другому семестрі студентам інших груп $(\mathrm{n}=65)$ лекції читали молоді асистенти, зі стажем викладацької роботи до 2 років, також займаються лікувальною роботою (2 група). Відбір студентів у групи був проведений методом випадкової вибірки, згідно із затвердженим у навчальному відділі ОНМедУ роз- 
кладом. Отримані дані ми опрацювали статистично і порівняли також з результатами диференційованого заліку наприкінці циклу “Онкологія”, тобто середній бал у групі студентів.

Найбільший інтерес і враження у студентів викликали лекції, прочитані професором і доцентами, на такі теми:

- Організація онкологічної допомоги. Методи діагностики та профілактики злоякісних утворень.

• Принципи лікування злоякісних пухлин.

- Рак шкіри та меланома.

- Рак молочної залози.

Дані теми є базовими згідно з затвердженою робочою програмою, і від якості та повноти їх викладу багато в чому залежить розуміння та засвоєння предмета "Онкологія" в цілому.

Істотний інтерес для кожного викладача, який бажає стати хорошим викладачем, майстром красномовства, представляють зразки не тільки лекційного викладання, але й ораторського мистецтва. Налекціях у вищій школі вчителю треба дивитися в аудиторію, ніби звертаючись персонально то до одного, то до іншого студента i до всіх разом. Треба також поєднувати голос, темп, інтонацію, міміку і жестикуляцію, але все повинно бути відповідно до змісту. Вчителю вищої школи необхідно систематично працювати над нагромадженням i поглибленням своїх знань і над вдосконаленням своєї педагогічної, у тому числі і лекторської, майстерності. Говорячи про педагогічні та психологічні якості лектора, треба звернути увагу на розвиток волі і вміння підпорядкувати собі аудиторію.

75 \% студентів першої групи в анкетах вказали, що найбільше їм сподобалася якість організації навчального процесу і проведення лекцій. 30 \% студентів першої групи вказали, що їм сподобалися всі 10 лекцій. При цьому 3 студенти першої групи виявили бажання брати активну участь у роботі наукового студентського гуртка “Онколог” і підготували тези доповідей, а згодом і усні доповіді на студентську конференцію. 30 \% студентів першої групи відповіли на запитання анкети: “Що вам не сподобалося?” короткий цикл, мало часу на вивчення онкології.

55 \% студентів другої групи в анкетах вказали, найбільше, що їм сподобалося, це якість організації навчального процесу, 80 \% студентів відзначили якість

\section{Література}

1. Вавилин Е. В. Проблемы подготовки научно-педагогических кадров в вузе / Е. В. Вавилин // Вестник СГАП. 2010. - №2 (72). - С. 171-174.

2. Пидкасистый П. И. Педагогика. Учебник для вузов / П. И. Пидкасистый. - М. : Юрайт, 2009. -430 с. ремонту і затишок у навчальних класах. 50 \% студентів другої групи вказали, що їм сподобалися всі 10 лекцій при цьому конспекти лекцій були лише у кожного 3 студента. Великий відсоток студентів, задоволених і вражених усіма 10 лекціями, може радувати тільки на перший погляд. Адже якщо задуматися, людина каже, що їй все подобається, коли насправді "все" трохи нижче середнього і вона не може запам' ятати або виділить щось особливе. Крім того, 10 \% студентів другої групи відзначили невпевненість лектора, нездатність читати лекцію без відриву від слайдів або те, що лекції були дуже короткі і прочитані в швидкому темпі. Жоден студент другої групи не захотів додатково вивчати онкологію і брати участь у роботі студентського наукового гуртка “Онколог”. Середній бал і оцінка на диференційованому заліку у студентів першої групи були об' єктивно вищими, ніж у студентів другої групи. Кількість студентів, не допущених до складання диференційованого заліку, з причини низького загального бала i/ або наявності пропущених занять (у тому числі лекцій), була більша в 2 рази в другій групі.

Таким чином, по закінченню експериментального навчального року, колектив кафедри зробив такі висновки:

1. Лекційна форма навчання не може бути замінена ніякою іншою. Відмова від лекцій знижує науковий рівень підготовки студентів, i тому лекція, як i раніше, повинна залишатися провідною формою організації навчального процесу на сучасному етапі кредитно-модульної системи навчання студентів вищого навчального закладу.

2. Для того щоб лекція стала живим, яскравим i змістовним повідомленням, необхідно обов'язково доповнити знання і професійний досвід широкою ерудицією, логікою аргументації, захопленістю своєю галуззю знань і внутрішньою потребою запалити нею студентів. А це означає, що лектору необхідно не тільки впливати на розум, але і на почуття своїх слухачів, тобто володіти відомими навичками красномовства.

3. Від майстерності викладача залежить максимальне використання потенційних можливостей цієї провідної форми навчання. Але процес навчання, починаючись на лекції, продовжується на практичних заняттях і поглиблюється самостійною роботою.

3. Смирнов С. Д. Педагогика и психология высшего образования / С. Д. Смирнов. - М., 2003.

Отримано 11.04.14 